\title{
RESPON BANK SYARIAH KOTA BENGKULU TERHADAP KEWENANGAN PENGADILAN AGAMA PADA PENYELESAIAN SENGKETA PERBANKAN SYARIAH
}

\author{
Elman Johari \\ Sekolah Tinggi Ilmu Ekonomi Syariah Nahdhatul Ulama \\ J. Pancurmas RT. 02 RW 01 Kelurahan Sukarami, Kecamatan Selebar Kota Bengkulu 38216 \\ Email: elmanjoehari@yahoo.co.id
}

\begin{abstract}
Sharia banking industry in Indonesia showed very rapid progress and Islamic principles which offered forbit riba,gharar, maisyir, and bathil. Nevertheless, the dispute in this industry will be inevitable, because the essence of dispute is a description to the harmonization of human interests. According the Article 49 point (i) of Law Number 3 of 2006 on the amendement of the Law Number 7 of 1989, Religious Court's have the authority to settle the sharia economics disputes therein, includes Sharia Banking. This provision in contradict with the explaination of Article 55 clause (1) of Law Number 21 of 2008 about Sharia Banking which give the general court an authority to settle it disputes.
\end{abstract}

Keywords: dispute, Sharia Bank, Court

\begin{abstract}
Abstrak: Lembaga perbankan syariah di Indonesia telah menunjukkan perkembangan yang pesat dan prinsip-prinsip Islam yang ditawarkan mengharamkan praktik riba, gharar, maisyir, dan bathil. Namun demikian, kemungkinan terjadinya konflik tidak bisa dihindari dalam industri ini karena esensi sengketa merupakan gangguan terhadap harmonisasi kepentingan manusia. Berdasarkan pasal 49 poin (i) Undang-Undang Nomor 3 Tahun 2006 tentang perubahan atas Undang-Undang Nomor 7 Tahun 1989, Peradilan Agama memiliki otoritas untuk menyelesaikan sengketa ekonomi, termasuk bank syariah. Ketentuan ini bertentangan dengan Pasal 55 ayat 1 Undang-Undang Nomor 21 Tahun 2008 tentang bank syariah yang memberikan kewenangan kepada pengadilan umum untuk menyelesaikan sengketa ini.
\end{abstract}

Kata kunci: sengketa, Bank Syariah, Peradilan

\section{Pendahuluan}

Lembaga perbankan syariah dalam koridor masyarakat yang sadar hukum saat ini, tidak dapat terhidar dari munculnya perselisihan yang berujung pada persengketaan antar para pihak, meskipun pada dasarnya setiap akad dibuat dengan landasan kepercayaan (trust). Persengketaan sendiri merupakan bagian tak terpisahkan dari kehidupan bersama umat manusia dimanapun diseluruh dunia, yang pada dasarnya merupakan suatu gangguan terhadap harmoni kepentingan manusia dan disebabkan adanya kepentingan yang saling bertentangan antara yang satu denagan yang lain. Untuk itu, dalam hal penanganan sengketa yang terjadi dalam lingkungan Bank Syariah juga seharusnya menggunakan pedoman yang sesuai dengan prinsip-prisip syariah dan tidak bertentangan dengan pranata hukum yang berlaku.

Diundangkanya Undang-Undang Nomor 3 Tahun 2006 tentang Perubahan Atas UndangUndang Nomor 7 Tahun 1989 tentang Peradilan Agama tidak mempengaruhi kewenangan BASYARNAS dalam menyelesaikan sengketa ekonomi Syariah karena berdasarkan UndangUndang Nomor 48 Tahun 2009 tentang Kekuasaan Kehakiman Pasal 58, upaya penyelesaian sengketa perdata dapat dilakukan di luar Pengadilan Negara melalui arbitrase atau alternatif penyelesaian sengketa lainnya. Hal tersebut menjadi sebuah polemik ditengah masyarakat dikarenakan beberapa faktor. Pertama, sebagaimana dirumuskan dalam Pasal 59 ayat (1) dan (4) Undang-Undang Nomor 30 Tahun 1999 
tentang Arbitrase dan Alternatif penyelesaian sengketa, putusan arbitrase tidak dapat dilaksanakan apabila dalam waktu paling lama 30 (tiga puluh) hari terhitung sejak tanggal putusan diucapkan, lembar asli atau salinan otentik putusan arbitrase tidak diserahkan dan didaftarkan oleh arbiter atau kuasanya kepada Panitera Pengadilan Negeri bukan kepada Pengadilan Agama. Senada dengan ketentuan tersebut, pada Pasal 59 ayat 3 Undang-Undang Nomor 48 Tahun 2009 tentang Kekuasaan Kehakiman seakan sebagai pelengkap eksistensi lembaga Arbitrase, dimana dirumuskan di dalamnya "apabila para pihak tidak secara suka rela melaksanakan putusan arbitrase, putusan dilaksanakan berdasarkan perintah ketua Pengadilan Negeri atas permohonan salah satu pihak yang bersengketa”.

Kedua, mengenai putusan eksekusi BASYARNAS sudah dikhususkan untuk diajukan ke Pengadilan Agama dengan diterbitkannya surat Edaran Mahkamah Agung (SEMA) Nomor 8 Tahun 2008, dimana didalamnya Pengadilan Agama sudah diberi kewenangan dalam hal eksekusi putusan BASYARNAS, akan tetapi kedudukan SEMA yang tidak termasuk dalam jenis dan heirarki peraturan Perundang-Undangan jo. Pasal 7 ayat (1) Undang-Undang Nomor 12 Tahun 2011 tentang Pembentukan Peraturan Perundang-Undangan tersebut tidak didukung dengan peraturan perundang-undangan yang diterbitkan setelahnya sehingga Surat Edaran Mahkamah Agung (SEMA) tersebut seakan hanya anjuran semata.

Disisi lain, juga terdapat persinggungan yurisdiksi antara kewenangan Pengadilan Agama dan Pengadilan Negeri dalam menangani sengketa Perbankan Syariah. Persinggungan dalam menangani sengketa perbankan syariah tersebut terdapat dalam rumusan Pasal 55 UndangUndang Nomor 21 Tahun 2008 tentang Perbankan Syariah yang menyebutkan: Ayat (1) Penyelesaian sengketa Perbankan Syariah dilakukan oleh pengadilan dalam lingkungan Pengadilan Agama. Ayat (2) Dalam hal para pihak telah memperjanjikan penyelesaian sengketa selain sebagaimana dimaksud pada ayat (1), penyelesaian sengketa dilakukan sesuai dengan isi akad. Ayat (3) penyelesaian sengketa sebagaimana dimaksud pada ayat (2) tidak boleh bertentangan dengan prinsip syariah.

Dalam penyelesaiannya yang dimaksud dengan "Penyelesaian sengketa dilakukan sesuai dengan isi akad" pada ayat (2) adalah upaya sebagai berikut: a) Musyawarah; b) Mediasi perbankan; c) Melalui Badan Arbitrase Syariah Nasional (BASYARNAS) atau lembaga arbitrase lainnya; dan/atau d) Melalui pengadilan dalam lingkungan Pengadilan Umum.

Pemahaman akan rumusan dalam Pasal 55 dan penjelasannya tersebut di atas secara rasional jelas terdapat inkonsistensi pembentuk Undang-Undang dalam merumuskan aturan hukum pada Pasal 49 huruf (i) UndangUndang Nomor 3 Tahun 2006 dengan menambahkan kewenangan Pengadilan Agama untuk memeriksa, memutuskan, dan mengadili perkara ekonomi syariah yang meliputi didalamnya jenis kegiatan usaha Perbankan Syariah. Bahkan, terbitnya Undang-Undang Nomor 50 Tahun 2009 tentang perubahan kedua Undang-Undang Nomor 7 Tahun 1989 tentang Peradilan Agama belum mengcover problematika yang ada.

\section{Profil Bank Syariah Kota Bengkulu}

Pertama, Bank Muamalat Indonesia (BMI). Lokasi: Jl. S. Parma No. 62 -3823. Bank Muamalat Indonesia, merupakan pelopor Bank Umum Syariah yang mulai beroprasai pada tahun 1992 dan menjadi salah satu penyebab yang melatarbelakangi eksistensi Lembaga Keuangan Syariah di Indonesia mendapatkan perhatian yang tinggi dari Pemerintah dengan lahirnya Undang-Undang Nomor 7 Tahun 1992 tentang Perbankan. Dimana dalam Pasal 6 huruf (m) dan Pasal (13) huruf (c), prinsip bagi hasil diperkenankan sebagai salah satu bentuk usaha Bank Umum. ${ }^{1}$

Kedua, Bank Rakyat Indonesia Syariah. Lokasi: Jl. S. Parman No. 51 A-B Kota Bengkulu - 38223. Bank Rakyat Indonesia Syariah, merupakan Strategic Bussiness Unit (SBU) dari

\footnotetext{
${ }^{1}$ Wawancara pribadi dengan Penambih Bambang Setijono, Bengkulu, 25 Februari 2016.
} 
BRI Syari'ah dengan menggunakan prinsip syariah. BRI Syariah Kota Bengkulu sendiri, telah menjalin kerjasama dengan beberapa lembaga dan perusahaan. ${ }^{2}$

Ketiga, Bank Negara Indonesia (BNI) Syariah Lokasi: Jl. Jenderal Sudirman No 41-43 RT 09 RW 13 Kelurahan Tengah Padang, Tlk. Segara Kota Bengkulu, Bengkulu 38115 (0736) 341996. Bank Negara Indonesia (BNI) Syariah merupakan Bank Umum Syariah (BUS) yang pada awalnya berstatus sebagai Unit Usaha Syariah (UUS) BNI yang bersifat temporer. ${ }^{3}$

\section{Penyelesaian Sengketa Perbankan Syariah}

Penyelesaian Sengketa Perbankan Syariah, secara spesifik telah diatur dalam Pasal 55 Undang-Undang Nomor 21 Tahun 2008 tentang Perbankan Syariah, yaitu: (1) Diselesaikan melalui Pengadilan dalam lingkungan Peradilan Agama; (2) Diselesaikan berdasarkan pilihan hukum maupun pilihan forum yang telah disepakati oleh para pihak (nasabah dan pihak Bank Syariah) dalam akad, dimana yang dimaksudkan adalah para pihak dapat memilih penyelesaian sengketa dengan upaya musyawarah-mufakat, mediasi, perbankan, melalui Badan Arbitrase Syariah Nasional (BASYARNAS) atau lembaga arbitrase lain, dan/ atau melalui pengadilan dalam lingkungan peradilan umum.

Penyelesaian sengketa melalui jalur musyawarah mufakat ini merupakan jalur paling awal diharapkan para pihak yang bersengketa dapat menyelesaikan masalahnya dengan cara baik-baik (musyawarah) sehingga sampai pada kesepakatan yang disetujui bersama (mufakat). Adapun cara selanjutnya, yaitu dapat dilakukan melalui mediasi perbankan yang diatur dalam Peraturan Bank Indonesia Nomor 8/5/PBI/2006 tentang Mediasi Perbankan dan Peraturan Bank Indonesia Nomor 10/1/PBI/2008 tentang Perubahan Atas Peraturan Bank Indonesia Nomor 8/5/PBI/2006 tentang Mediasi Perbankan. Pasal

\footnotetext{
2 Wawancara pribadi dengan Tanti Widya, Bengkulu, 15 Februari 2016.

${ }^{3}$ Wawancara Pribadi dengan Ainul Yaqin, Bengkulu, 20 Maret 2016.
}

1 ayat (5) Peraturan Bank Indonesia Nomor 8/5/ PBI/2006 menyatakan bahwa mediasi adalah proses penyelesaian sengketa yang melibatkan mediator untuk membantu para pihak yang bersengketa guna mencapai penyelesaian dalam bentuk kesepakatan sukarela terhadap sebagian atau seluruh permasalahan yang disengketakan.

Tidak seperti arbitrase atau hakim, seorang mediator tidak membuat keputusan mengenai sengketa yang terjadi tetapi hanya membantu para pihak untuk mencapai tujuan mereka dan menemukan pemecahan masalah dengan hasil win win solution sehingga tidak ada pihak yang kalah ataupun menang. Penyelesaian sengketa selanjutnya dapat dilakukan melalui Arbitrase Syariah Nasional (BASYARNAS). Dalam perspektif Islam arbitrase dapat disepadankan dengan istilah tahkim, berasal dari kata hakkama, secara etimologis berarti menjadikan seseorang sebagai pencegah suatu sengketa. Pengertian Arbitrase berdasarkan Pasal 1 ayat (1) UndangUndang Nomor 30 Tahun 1999 Tentang Arbitrase dan alternatif penyelesaian sengketa bahwasannya arbitrase adalah cara penyelesaian sengketa perdata diluar peradilan umum yang didasarkan pada perjanjian arbitrase yang dibuat secara tertulis oleh pihak yang bersengketa.

Penelitian ini bertujuan (1) mengetahui respon Lembaga Keuangan Perbankan Syariah di Kota Bengkulu dalam hal penyelesaian sengketa sesuai yang terangkum pada Pasal (55) Undang-Undang perbankan syariah Nomor 21 Tahun 2008. (2) mengetahui faktor-faktor terjadinya persinggungan dalam wewenang lingkungan peradilan yang berbeda dalam hal penyelesaian sengketa pada Pasal (55) UndangUndang Nomor 21 Tahun 2008 menurut lembaga keuangan syariah di Kota Bengkulu.

\section{Metode Penelitian}

Penelitian ini tergolong kedalam jenis penelitian lapangan (Empiris) karena penelitian ini dilakukan dilingkungan Bank Syariah Kota Bengkulu, dengan didukung jurnal kepustakaan (library raseach), dan berpedoman pada UndangUndang tentang Perbankan Syariah (normative). Pendekatan yang digunakan merupakan jenis 
pendekatan kualitatif dengan jenis penelitian deskriptif. Metode analisis data lapangan yang digunakan adalah editing, verifying, classifying, analizying, dan concluding.

Data primer dalam penelitian ini, adalah hasil interview penulis dengan bagian yang ditunjuk langsung oleh Bank Syariah sebagai bagian yang mengerti dan berkompetensi dalam hal sengketa Perbankan Syariah, yaitu: (1) Penambih Dendi Prasetyo sebagai Relationship Manager Remedial (RM Remedial) di Bank Muamalat Indonesia Cabang Kota Bengkulu; (2) Cica Hayati sebagai Meneger Operasional di Bank Rakyat Syariah Cabang Kota Bengkulu; (3) Ainul Yaqin sebagai Recovery and Remedial di Negara Indonesia (BNI) Syariah Cabang Kota Bengkulu. Sedangkan data sekunder yang paling utama dalam penelitian ini adalah Undang-Undang Nomor 21 Tahun 2008 tentang Perbankan Syariah.

\section{Prosedur Pengadilan Agama Dalam Menyelesaikan Perkara Perbankan Syariah}

Seperti salah salah satu asas hukum acara perdata adalah "hakim wajib mengadili setiap perkara yang diajukan kepadanya" Asas ini bersumber dari ketentuan Pasal 10 ayat (1) UndangUndang Mahkamah Agung Nomor 48 Tahun 2009 yang menyatakan bahwa: "Pengadilan tidak boleh untuk memeriksa, mengadili dan memutus sesuatu perkara yang diajukan dengan dalih bahwa bukum tidak ada atau kurang jelas, melainkan wajib untuk memeriksa dan mengadilinya".

Dari ketentuan pasal tersebut dapat dipahami bahwa terhadap perkara perdata yang diajukan ke Pengadilan, termasuk dalam hal ini perkara Perbankan Syariah yang diajukan ke Pengadilan Agama, pengadilan tersebut harus menyelesaikannya meskipun hukum materiil mengenai penyelesaian sengketa perbankan syariah belum ada, karena Hakim merupakan individu yang diangkat oleh Negara sebagai individu yang dianggap tahu dan mengerti hukum (ius curia novit).

Terhadap perkara-perkara yang diajukan ke pengadilan, sesuai dengan ketentuan tersebut penyelesaiannya hanya ada dua kemungkinan, yaitu: (1) Diselesaikan melalui perdamaian atau apabila upaya damai tersebut tidak berhasil; (2) Diselesaikan melalui proses persidangan (litigasi) seperti biasa seperti ketentuan hukum acara perdata yang berlaku. Kedua cara inilah yang harus ditempuh Pengadilan Agama dalam menyelesaikan perkara-perkara dibidang ekonomi syariah umumnya dan dibidang perbankan syariah khususnya yang diajukan kepadanya. ${ }^{4}$

Pertama, penyelesaian melalui perdamaian. Terkait upaya damai yang harus dilakukan hakim dalam rangka menyelesaikan perkaraperkara dibidang ekonomi syariah umumnya dan dibidang perbankan syariah khususnya dilingkungan Peradilan Agama, paling tidak ada dua ketentuan yang harus diperhatikan yaitu: ketentuan Pasal 154 R.Bg/130 HIR dan peraturan Mahkamah Agung (PERMA) Nomor 01 Tahun 2008 tentang prosedur mediasi di pengadilan.

Upaya mendamaikan kedua belah pihak yang berperkara di persidangan adalah sesuatu yang imperatife' (wajib dilakukan). Kelalaian hakim dalam mengupayakan perdamaian bagi kedua belah pihak beperkara akan mengakibatkan batalnya pemeriksaan perkara tersebut demi hukum..$^{5}$ Artinya, selama proses mediasi belum benar-benar dilakukan sesuai dengan tahapantahapan yang diatur dalam PERMA, maka pemeriksaan menurut hukum acara perdata biasa (litigasi) tidak boleh dilakukan. Upaya damai sebagaimana yang dimaksud, terhadap dua alternatif. Pertama, secara sukarela tanpa bantuan mediator (voluntary), dan dengan bantuan mediator. Setelah dipastikan bahwa anjuran damai secara sukarela seperti dikehendaki Pasal 154 R.Bg/130 HIR tidak berhasil atau tidak mungkin lagi dapat ditempuh, barulah hakim memerintahkan para pihak tersebut untuk menempuh prosedur mediasi dengan bantuan mediator sebagaimana yang dikehendaki oleh PERMA tersebut.

Kedua, upaya damai melalui mediasi. Mediasi yang diterapkan dalam sistem peradilan menurut ketentuan Pasal 1 butir 7 PERSEMA diartikan

${ }^{4}$ Basir, Cik. Penyelesaian Sengketa Perbankan Syariah Di Pengadilan Agama \& Mahkamah Syariah. Jakarta: Prenada Perdana Group, 2009) h. 127.

5 M. Yahya Harahab, "Hukum Acara Perdata", (Jakarta: Sinar Grafika, 2005), h. 239 
sebagai: "Cara penyelesaian sengketa melalui proses perundingan untuk memperoleh kesepakatan para pihak dengan dibantu oleh mediator." Adapun kedudukan dan fungsi mediator dalam proses perundingan tersebut menurut Pasal 1 butir (6) PERMA adalah sebagai pihak yang netral (tidak memihak) yang membantu para pihak dalam proses perundingan guna mencari berbagai kemungkinan penyelesaian sengketa tanpa menggunakan cara memutus atau memaksakan sebuah penyelesaian tertentu. Dengan demikian, terdapat semua sengketa perdata yang diajukan kepengadilan tingkat pertama harus terlebih dahulu diupayakan penyelesaiannya melalui proses mediasi. Pengecualiannya tentu saja dalam hal ini sepanjang perkara tersebut bukan perkara yang menurut undang-undang tidak bisa diselesaikan melalui perdamaian, seperti misalnya perkara perceraian, perkara mengenai status seseorang, hibah, wasiat dan lain-lain. ${ }^{6}$

Ketiga, penyelesaian melalui proses persidangan. Proses pemeriksaan dan penyelesaian sengketa melalui proses persidangan (litigasi) merupakan upaya penyelesaian sengketa setelah bentuk penyelesaian perdamaian dan mediasi tersebut tidak berhasil, dimana kedua belah pihak ternyata gagal dalam menyelesaikan perkaranya secara damai sehingga sesuai dengan ketentuan Pasal 155 R.Bg atau Pasal 131 HIR Ayat (1) dan (2) jo. Pasal 18 Ayat (2) PERMA hakim harus melanjutkan pemeriksaan perkara tersebut sesuai dengan ketentuan hukum acara yang berlaku.

Adapun prinsip utama yang harus benarbenar dipahami dan diperhatikan dalam menangani perkara perbankan syariah khususnya dan perkara bidang ekonomi syariah pada umumnya bahwa dalam proses penyelesaian perkara tersebut sama sekali tidak boleh bertentangan dengan prinsip syariah karena prinsip fundamental dalam menjalankan kegiatan usahanya tidak lain berdasarkan prinsip syariah.

Sebagaimana uraian terdahulu, bahwa penyelesaian perkara perbankan syariah dilingkungan Peradilan Agama akan dilakukan sesuai dengan ketentuan hukum acara perdata

${ }^{6}$ M. Yahya Harahab, Arbitrase. (Jakarta: Sinar Grafika, 2001) .h. 249. sebagaimana yang berlaku dilingkungan peradilan umum. Dengan demikian dalam hal ini proses pemeriksaan perkara tersebut akan berjalan sebagaimana lazimnya proses pemeriksaan perkara perdata di pengadilan yang secara umum. ${ }^{7}$

\section{Respon Bank Syariah Kota Bengkulu Terhadap Kewenangan Pengadilan Agama di Bidang Penyelesaian Sengketa}

Terjadinya sengketa pada umumnya, karena adanya penipuan atau ingkar janji oleh pihakpihak, atau salah satu pihak tidak melakukan apa yang dijanjikan/ disepakati untuk dilakukan. Potensi terjadinya sengketa hampir ada disetiap kegiatan usaha karena dalam suatu transaksi bisnis, tidak selalu berjalan mulus seperti apa yang dinginkan oleh para pihak yang terkait walaupun telah diatur oleh undang-undang, dan/ atau telah diadakan perjanjian antara pelaku usaha, yang telah disepakati bersama.

Pola penyelesaian sengketa Perbankan Syariah sebagaimana yang penulis jabarkan sebelumnya, dapat disimpulkan bahwa upaya penyelesaian sengketa melalui proses pengadilan merupakan muara dari upaya penyelesaian lain yang sebelumnya telah dilalui oleh pihak yang terkait. Dengan kata lain, upaya perdamaian yang putusannya bersifat win-win solution lebih diutamakan. Meskipun demikian, pola penyelesaian disetiap Bank Syariah yang menjadi objek penelitian dalam pembahasan ini, mempunyai pola dan karakteristik yang disesuaikan berdasarkan status dan kebijakan yang menjadi pedoman operasional masing-masing lembaga.

Adapun persamaan dari ketiga Bank Syariah yang penulis teliti berpendapat bahwa mayoritas permasalahan atau sengketa yang ada diantara Bank dengan nasabah adalah masalah pemenuhan hak dan kewajiban dalam pembiayaan yang diberikan oleh Bank Syariah. Kegiatannya juga sepakat menggunakan metode Restructurasi pembiayaan yang meliputi 3 (tiga) yaitu: penjadwalan kembali (rescheduling), persyaratan kembali (reconditioning), dan penataan kembali (restructuring).

${ }^{7}$ Mukti Arto, A.. Praktik Perkara Perdata Pada Pengadilan Agama. (Yogyakarta: Pustaka Pelajar, 1996) h. 65 
Hal tersebut diatur dalam Surat Edaran Bank Indonesia (SEBI) Nomor 10/34/DPbS tahun 2008 sebagai berikut: 1) Penjadwalan kembali (rescheduling), yaitu perubahan jadwal pembayaran kewajiban nasabah atau jangka waktunya. 2) Persyaratan kembali (reconditioning), yaitu perubahan sebagian atau seluruh persyaratan pembiayaan, antara lain perubahan jadwal pembayaran, jumlah angsuran, jangka waktu dan/atau pemberian potongan sepanjang tidak menambah sisa kewajiban nasabah yang harus dibayarkan kepada BUS atau UUS; dan/atau; 3) penataan kembali (restructuring), yaitu perubahan persyaratan pembiayaan yang tidak terbatas pada rescheduling atau reconditioning.

\section{Melalui Proses Adjudikatif 8}

Ciri dari proses adjudikatif ditandai dengan kewenangan pengambilan keputusan oleh pihak ketiga dalam sengketa yang berlangsung diantara para pihak dan dalam kaitannya dengan penyelesaian sengketa dalam Pasal 55 Undang-Undang Nomor 21 Tahun 2008 tentang Perbankan Syariah, penyelesaian sengketa melalui jalur pengadilan dalam lingkungan Peradilan Agama dan Peradilan Negeri merupakan bentuk dari adjudikasi publik dan penyelesaian melalui BASYARNAS merupakan bentuk dari adjudikasi privat.

Kesatu, melalui jalur pengadilan agama. The Last Resort dari suatu penyelesaian sengketa adalah melalui lembaga peradialan, akan tetapi sebelum sampai pada tahap persidangan hakim pengadilan juga diwajibkan melaksanakan terlebih dahulu penyelesaian sengketa melalui perdamaian bank secara sukarela (voluntary) ataupun perdamaian dengan mediasi. Karena apabila prosedur tersebut tidak dilaksanakan akan mengakibatkan putusan pengadilan batal demi hukum.

Meskipun sudah berjalan selama kurang lebih 6 tahun sejak diterbitkannya Undang-Undang Nomor 3 Tahun 2006 tentang Perubahan atas Undang-Undang Nomor 7 Tahun 1989 tentang Peradilan Agama sebagai batu pijakan bertambahnya kewenangan absolut Pengadilan

\footnotetext{
${ }^{8}$ Dadan Muttaqien, dan Fakhruddin Cikman. Penyelesaian Sengketa Perbankan Syariah. (Yogyakarta: Kreasi Total Media, 2008) h. 30
}

Agama untuk memeriksa, memutuskan dan menyelesaikan perkara ekonomi syariah meliputi di dalamnya kegiatan perbankan syariah, belum berjalan sebagaimana mestinya, baik dikarenakan kondisi sosial maupun politik. ${ }^{9}$

Respon dari praktisi perbankan syariah akan penulis uraikan demi penyempurnaan peraturan sehingga prinsip syariah benar-benar dapat diterapkan.

Menurut Penambih Bambang Sutijono (Bank Muamalat Indonesia Cabang Bengkulu) menyatakan bahwa: "Pengadilan Agama belum siap dalam menangani sengketa Perbankan Syariah, karena meskipun hukum acara yang dilaksanakan dalam Peradilan Negeri, kajian Perbankan Syariah sangatlah luas bukan hanya mencakup standart perjanjian dalam KUHP Perdata dan sengketa yang dimungkinkan terjadi bukan hanya sengketa perdata melainkan juga pidana. Sedangkan, selama ini Hakim-Hakim Pengadilan Agama hanya terbiasa menangani hukum perdata keluarga saja."

Dari pernyataan diatas, menunjukkan bahwa kesiapan hakim Pengadilan Agama dalam menangani sengketa perbankan syariah masih diragukan. Terlebih lagi Penambih Bambang juga pernah mendapatkan penolakan atas sengketa yang diajukannya di Pengadilan Agama Kota Bengkulu. Hal ini tentunya bertentangan dengan asas hukum acara perdata, bahwa "hakim wajib mengadili setiap perkara yang diajukan kepadanya" yang bersumber dari ketentuan Pasal 10 (1) UU No. 48 Tahun 2009 tentang Kekuasaan Kehakiman yang menyatakan bahwa: "Pengadilan tidak boleh menolak untuk memeriksa, mengadili dan memutus sesuatu perkara yang diajukan dengan dalih bahwa hukum tidak ada atau kurang jelas, melainkan wajib untuk memeriksa dan mengadilinya". Adapun respon dari Tanti Widia (Bank Rakyat Indonesia Syariah Cabang Bengkulu): "Sebenarnya tidak masalah kalau Pengadilan Agama menangani sengketa Perbankan Syariah, tapi Bank Rakyat Indonesia Syariah untuk saat ini masih merujuk kepada Bank Rakyat Indonesia Syariah sebagai kantor pusat kami."

Status Bank Rakyat Indonesia Syariah sebagai

${ }^{9}$ Grofur Anshor, Abdul. Perbankan Syariah. (Yogyakarta: Gajdah Mada University Press, 2009) h. 36 
UUS dari Bank Rakyat Indonesia Konvensional, membuat posisinya tidak tentu arah, hal tersebut dapat dilihat dari ketidak jelasan hukum yang digunakan sebagaimana termasuk dalam Pasal 23 tentang hukum yang berlaku dalam Pembiayaan Kepemilikan Rumah Indent Syariah Bank Rakyat Indonesia Syariah yang didalam Pasal 3 disebutkan: "Bilamana musyawarah sebagai dimaksud ayat (1) Pasal ini, tidak menghasilkan kata sepakat mengenai penyelesaian perselisihan, maka semua sengketa yang timbul dari akad ini akan diselesaikan dan diputus baik melalui Bank Arbitrase Syariah Nasional (BASYARNAS); Pengadilan Agama; Pengadilan Negeri; KP2LN dan atau Balai Lelang Swasta yang keputusannya mengikat kedua belah pihak yang bersengketa."

Meskipun demikian, beliau merespons penyelesaian sengketa melalui Pengadilan Agama dengan cukup baik. Respons dari Ainul Yaqin (Bank Rakyat Indonesia Syariah): "Saat ini memang BRIS sudah menggunakan Pengadilan Agama sebagai upaya penyelesaian sengketa Perbankan Syariah, dan sudah pernah kami ajukan pada akhir tahun 2016, tapi karena prosedur butuh waktu lama sampai saat ini perkaranya belum diputus."

Dari uraian tersebut dapat dikatakan bahwa BRI Syariah merespons dengan sangat baik, dengan ikut mengaplikasikan ketentuan dalam peraturan perundang-undangan.

Kedua, melalui jalur Pengadilan Negeri. Dalam hal pembentuk undang-undang masih memberikan kewenangan bagi Pengadilan Negeri untuk menyelesaikan dan memutuskan sengketa Perbankan Syariah, menimbulkan kaburnya makna kewenangan absolut Pengadilan Agama. Karena pada hakikatnya kewenangan absolut masing-masing Pengadilan Negara berbeda sesuai dengan karakteristik pengadilan tersebut dan disesuaikan sesuai porsi masing-masing.

Penambih Bambang Setijono sependapat dengan pembentuk undang-undang dikarenakan yang terkait dengan kegiatan usaha perbankan secara nasional masih menjadi kewenangan Pengadilan Negeri, misalnya Undang-Undang Nomor 42 Tahun 1999 tentang Fidusia dan Undang-Undang Nomor 4 Tahun 1996 tentang Hak Tanggungan.
Ketiga, melalui Badan Arbitrase Syariah Nasional (BASYARNAS). Upaya hukum penyelesaian sengketa dengan menggunakan proses pengadilan di BASYARNAS, termaktub dalam klausul akad pembiayaan Hunian Syariah Bank Muamalat Indonesia Pasal 19 ayat (3) yang di dalamnya dicantumkan: "Dalam hal musyawarah untuk mufakat sebagaimana dimaksud ayat 1 Pasal ini tidak tercapai, maka Para Pihak bersepakat dan dengan ini berjanji serta mengikatkan diri satu terhadap yang lain, untuk menyelesaikannya melalui Badan Arbitrase Syariah Nasional (BASYARNAS) menurut peraturan dan prosedur yang berlaku di dalam Badan Arbitrase tersebut."

Terdapat pula dalam Pasal 23 ayat (3) Akad Pembiayaan Kepemilikan Rumah Indent Syariah Bank Rakyat Syariah, yang didalamnya disebutkan: "Bilamana musyawarah sebagai dimaksud ayat (1) Pasal ini, tidak menghasilkan kata sepakat mengenai penyelesaian perselisihan, maka semua sengketa yang timbul dan Akad ini akan diselesaikan dan diputus baik melalui Badan Arbitrase Syariah Nasional (BASYARNAS)."

Sedangkan, Bank Negara Indonesia Syariah, tidak menggunakan lembaga BASYARNAS dalam penyelesaian sengketa Perbankan Syariah. Meskipun demikian, Ainul Yaqien tetap merespons baik dengan mengatakan: "Saat ini, dalam akad kami tidak menggunakan Lembaga BASYARNAS, tapi kalau nasabah menghendaki lain yang kami terima." Disisi lain, ternyata lembaga ini dinilai belum mampu dalam menyelesaikan sengketa Perbankan Syariah, sebagaimana pendapat Penambih Bambang Setijono ketika penulis wawancarai: "Pencatuman Lembaga BASYARNAS dalam akad tersebut hanya formalitas, karena selain Sumbar Daya Manusia yang belum siap juga seperti kerja dua kali karena eksekusi putusannya tetap di Pengadilan Negeri sebagaimana dalam UU Arbitrase".

Mengenai substansi tersebut tercantum dalam ayat selanjutnya disebutkan: "Mengenai pelaksanaan (eksekusi) putusan BASYARNAS, sesuai dengan ketentuan Undang-Undang Nomor 30 Tahun 1999 tentang Arbitrase dan Alternatif Penyelesaian Sengketa, Para Pihak sepakat bahwa Para Pihak dapat meminta pelaksanaan (eksekusi) putusan 
BASYARNAS tersebutpada Pengadilan Negeri [....]." Senada dengan pendapat tersebut, Tanti Widia juga menilai negatif eksistensi Lembaga BASYARNAS dengan mengatakan: "Lembaga BASYARNAS itu ada, tapi kantornya kosong."

\section{Melalui Proses Konsensual}

Ciri dari mekanisme penyelesaian sengketa konsensual yaitu penyelesaian sengketa secara kompromis untuk mencapai solusi yang bersifat win win solutions. Dalam hal penyelesaian sengketa berdasarkan Undang-Undang Nomor 21 Tahun 2008 tentang Perbankan Syariah, musyawarah mufakat, dan mediasi perbankan termasuk dalam mekanisme penyelesaian sengketa Perbankan Syariah Konsensual.

Pertama, melalui musyawarah. Upaya penyelesaian sengketa dengan menggunakan prosedur musyawarah antara pihak-pihak yang terkait dalam sengketa perbankans yariah ini, mendapatkan respon yang sangat baik. Dimana dari ketiga Bank Syariah di Kota Bengkulu yang menjadi objek penelitian penulis, ketiga-tiga menggunakan prosedur ini sebelum menggunakan upaya hukum lainnya. Sebagaimana yang tertuang dalam Pasal 19 ayat (1) akad pembiayaan Hunian Syariah yang digunakan oleh Bank Muamalat Indonesia yang berisi: "Apabila dikemudian hari terjadi perbedaan atau penafsiran atas hal-hal yang tercantum didalam akad ini atau terjadi perselisihan atau sengketa dalam pelaksanaan akad ini, para pihak sepakat untuk menyelesaikannya secara musyawarah untuk mufakat".

Subtansi yang sama juga dicantumkan dalam akad Pembiayaan Kepemilikan Rumah Indent Syariah Cabang Bengkulu, yang tertuang dalam Pasal 23 ayat (2): "Apabila dikemudian hari terjadi perselisihan dalam penafsiran atau pelaksanaan ketentuan-ketentuan dari akad, maka para pihak sepakat untuk terlebih dahulu menyelesaikan secara musyawarah untuk mufakat"

Selanjtnya Ainul Yaqin, yang menjabat sebagai recovery and Remedial di Bank Negara Indonesia Syariah cabang Kota Bengkulu, menyatakan: "Musyawarah itu tentu dilakukan, untuk mengetahui sebenarnya apa yang terjadi dilapangan atau nasabah secara lisan dan kekeluargaan jadi kalau masalah masih bisa diatasi kami masih bisa memberikan dispensasi keringanan baik dalam bentuk materi atau non-materi"Io

Uraian diatas, menunjukkan bahwa jalur musyawarah untuk mencapai suatu mufakat atau kesepakatan antara pihak yang terkait dinilai masih menjadi jalan favorit, karena selain permasalahan dapat diselesaikan secara kekeluargaan, masingmasing pihak juga tidak ada yang kalah ataupun menang. Karena secara garis besar, upaya ini merupakan upaya untuk mengetahui sebab-sebab terjadinya masalah atau sengketa dan bersamasama mencari jalan keluar dari masalah tersebut.

Kedua, melalui mediasi perbankan. Upaya Mediasi perbankan merupakan upaya dengan pihak Bank Indonesia sebagai mediator antara pihak Bank dan nasabah yang terkait dalam suatu sengketa. Upaya ini sama sekali tidak dicantumkan dalam klausul akad perjanjian yang dalam hal ini adalah Bank Muamalat Indonesia dan Bank Negara Indonesia Syariah cabang Bengkulu. Senada dengan uraian tersebut, Penambih Bambang Setijono, selaku Relationship Manager and Remedial Bank Muamalat Indonesia, berpendapat: "Kami pihak Bank Syariah merespons baik mengenai peraturan yang terkait dengan Perbankan Nasionalkhususnya terkait Perbankan Syariah, akan tetapi, ya harus disesuaikan dengan kabutuhan Bank juga"l

Hal tersebut dikarenakan bahwa sengketa yang ada mayoritas hanya terkait pembiayaan dengan pemberian jaminan sehingga sebelum sengketa ditangani langsung olah Bank Indonesia, Bank Syariah sudah mempunyai kewenagan untuk melelang aset berharga yang dijaminkan oleh nasabah kepada Bank Syariah, sebagaimana yang disampaikan oleh Tanti Widya, selaku Manager Operasional Bank Rakyat Indonesia Syariah Cabang Bengkulu: "Penyelesaian tidak sampai ke BI, karena kita sudah punnya wewenang sendiri untuk melakukan eksekusi barang jaminan."I2

${ }_{10}$ Wawancara Pribadi dengan Ainul Yaqin, Bengkulu, 22 Maret 2016.

${ }^{11}$ Wawancara pribadi dengan Penambih Bambang Setijono, Bengkulu, 27 Februari 2016.

${ }_{12}$ Wawancara pribadi dengan Tanti Widya, Bengkulu, 20 Februari 2016. 


\section{Persinggungan Kewenangan antara Peradilan Agama dan Peradilan Negeri}

Latar belakang persinggungan kewenangan dalam menangani sengketa Perbankan Syariah menurut para praktisi Bank Syariah Kota Bengkulu yang termaktub dalam penjelasan Pasal 55 Undang-Undang Nomor 21 Tahun 2008 tentang Perbankan Syariah yang disebutkan didalamnya: (a) Penyelesaian sengketa Perbankan Syariah dilakukan oleh Pengadilan dalam lingkungan Peradilan Agama. (b) Dalam hal ini para pihak telah memperjanjikan penyelesaian sengketa selain sebagaimana dimaksud pada ayat (1), penyelesaian sengketa dilakukan sesuai dengan isi akad. (c) penyelesaian sengketa sebagaimana dimaksud pada ayat (2) tidak boleh bertentangan dengan prinsip Syari ${ }^{2}$ ah.

Dalam penjelasan Pasal 55 ayat (2) dinyatakan, bahwa yang dimaksud dengan "Penyelesaian sengketa dilakukan sesuai dengan isi akad' adalah upaya sebagai berikut: (a) Musyawarah; (b) Mediasi Perbankan; (c) Melakukan Badan Arbitrase Syariah Nasional (BASYARNAS) atau lembaga arbitrase lain; dan/atau (d) Melalui pengadilan dalam lingkungan peradilan umum.

Berdasarkan pendapat-pendapat para praktisi yang menjadi sumber data primer dalam penelitian ini akan penulis uraikan sebagai berikut:

\section{Pendapat Penambih Bambang Setijono (Bank Muamalat Indonesia)}

Lahirnya Undang-Undang Nomor 3 Tahun 2006 tentang perubahan atas Undang-Undang Nomor 7 Tahun 1989 tentang Peradilan Agama yang dijadikanya kunci diberikannya kewenangan Absolut kepada Pengadilan Agama dalam hal penyelesaian sengketa Ekonomi Syariah pada Pasal 49 huruf (i), yang pada penjelasannya di dalamnya meliputi salah satunya adalah jenis kegiatan Perbankan Syariah, lahir jauh setelah dibentuknya Perusahaan Bank Syariah di Indonesia, yaitu dipelopori dengan di bentuknya Bank Muamalat Indonesia pada tanggal 1 November 1991. Sedangkan sejak didirikannya Bank Syariah tersebut, dalam menjalankan kegiatan usahanya yang harus berpedoman kepada peraturan Perundang-Undangan yang menunjang, seperti
Undang-Undang Nomor 4 Tahun 1996 tentang Hak Tanggungan dan Undang-Undang Nomor 42 Tahun 1999 terntang Fidusia belum disempurnakan. Dimana pada kedua UndangUndang tersebut, apabila terjadi dan timbul persengketaan atau perselisihan masih menjadi kewenanagan Pengadilan Negeri.

\section{Pendapat Tanti Widia (Bank Rakyat Indonesia (BRIS) Syariah)}

Bank Rakyat Indonesia (BRI) Syariah yang masih berstatus sebagai Strategic Bussiness Unit (SBU) dari Bank Rakyat Indonesia Konvensional, atau dalam Undang-Undang Nomor 21 Tahun 2008 tentang Perbankan Syariah lebih dikenal dengan istilah Unit Usaha Syariah (UUS) sebagai bentuk pengaplikasian produk yang menggunakan prinsip Syariah dalam industri perbankan konvensional, tidak terlalu banyak memberikan pendapat mengenai persinggungan kewenangan antara Pengadilan Agama dan Pengadilan Umum dalam hal penyelesaian sengketa Perbankan Syariah. Dimana Tanti Widia mengemukakan bahwa: "Dari aspek hukum Bank Rakyat Indonesia (BRI) Syariah ini tidak mengacu ke Pengadilan Agama, dan masih mengacu kepada Bank pusat kami"

Kalimat "Bank Pusat" yang dimaksud dalam ungkapan ini dimaksudkan adalah Bank Rakyat Indonesia (BRI) Konvensional yang masih mempercayakan prosedur penyelesaian sengketanya kepada Pengadilan Negeri. Lebih lagi dalam menjalankan statusnya sebagai Strategic Bussiness Unit dari Bank Rakyat Indonesia Konvensional yang fokus untuk mendapatkan keuntungan yang sebanyak-banyaknya, mayoritas kendala, perselisihan, dan sengketa yang dihadapi merupakan sengketa yang berhubungan dengan jaminan yang untuk eksekusi pelelangannya dibantu oleh Pengadilan Negeri dan Kantor Pelayanan Kekayaan Negara dan Lelang (KPKNL). Dengan demikian adanya UUS juga mempengaruhi dualisme kewenangan antara Pengadilan Agama dan Pengadilan Negeri dalam hal penyelesaian sengketa Perbankan Syariah. ${ }^{13}$

${ }^{13}$ Rachmadi Usman. Aspek Hukum Perbankan Syariah di Indonesia. (Jakarta Sinar Grafika, 2012) h. 42 
Pendapat Ainul Yaqin (Bank Negara Indonesia (BNI) Syariah)

Pengetahuan dan pemahaman nasabah mengenai kewenangan Pengadilan Agama dalam menyelesaikan sengketa Perbankan Syariah sangatlah minim. Dan pada faktanya Pendirian Bank Syariah bukan hanya dikhususkan untuk kalangan Muslim tetapi juga non-Muslim. Adanya pilihan hukum dan forum sebagaimana yang termaktub dalam Pasal 55 Undang-Undang Nomor 21 Tahun 2008 tentang Perbankan Syariah, beliau anggap sebagai salah satu pengaplikasian dalam asas kebebasan berkontrak sebagai asas umum dalam suatu perjanjian.

Selain itu, kebiasaan nasabah dalam menyelesaikan suatu sengketa dengan menggunakan prosedur penyelesaian sengketa dalam peradilan dalam lingkungan Pengadilan Negeri, menurut beliau juga dapat dijadikan sebagai salah satu latar belakang. Dimana Pengadilan Negeri juga berwenang dalam menyelesaikan sengketa perdata dan pidana secara umum sebagaimana disebutkan dalam Undang-Undang Nomor 8 Tahun 2004 tentang perubahan atas UndangUndang Nomor 2 Tahun 1986 tentang Peradilan Umum, dalam Pasal 50 menyatakan: "Pengadilan Negeri bertugas dan berwewenag memeriksa, memutus dan meyelesaikan perkara pidana dan perkara perdata di tingkat pertama."

\section{Penutup}

Latar belakang persinggungan kewenangan antara Pengadilan Agama dengan Pengadilan Negeri, menurut para praktisi perbankan syariah Kota Bengkulu adalah: (1) Mengantisipasi adanya kemungkinan sengketa pidana di bidang perbankan syariah (2) Kesiapan hakim Pengadilan Agama menurut beberapa pihak masih hanya bersifat kesiapan standar materi perjanjian, dimana belum memahami secara maksimal seluk beluk bidang-bidang hukum bisnis, seperti reksadana, keuangan mikro, dan urusan ekonomi syariah lainnya yang semakin kompleks dan berkembang pesat; (3) Masih banyaknya peraturan perundangundangan yang terkait dengan kegiatan usaha perbankan secara nasional yang belum disesuaikan dan masih menjadi kewenangan Pengadilan
Negeri apabila terjadi suatu sengketa, misalnya Undang-Undang Fidusia; (4) Peminat bank syariah bukan hanya dari kalangan muslim saja, akan tetapi juga non-muslim; (5) Masih adanya UUS yang secara operasional masih merujuk kepada Bank Konvensionalnya sebagai bank pusat; (6) Pengadilan Agama masih dalam masa transisi untuk mengoptimalkan keilmuan dibidang ekonomi syariah, khususnya perbankan syariah.

\section{Pustaka Acuan}

Arto, A. Mukti. Praktik Perkara Perdata Pada Pengadilan Agama. Yogyakarta: Pustaka Pelajar, 1996.

Bambang Penambih Setijono, Wawancara tanggal 27 Februari 2016.

Basir, Cik. Penyelesaian Sengketa Perbankan Syariah Di Pengadilan Agama \& Mahkamah Syariah. Jakarta: Prenada Perdana Group, 2009.

Grofur Anshor, Abdul. Perbankan Syariah. Yogyakarta: Gajdah Mada University Press, 2009.

Harahap, M. Yahya. Arbitrase. Jakarta: Sinar Grafika, 2001.

Hukum Acara Perdata. Jakarta: Sinar Grafika., 2005.

Muttaqien, Dadan dan Fakhruddin Cikman. Penyelesaian Sengketa Perbankan Syariah. Yogyakarta: Kreasi Total Media, 2008.

Subekti, R dan R. Tjitrosudibio. Kitab UndangUndang Hukum Perdata (Burgerlijk Wetboek). Jakarta: Pradnya Pratamita, 2001.

Usman, Rachmadi. Aspek Hukum Perbankan Syariah di Indonesia. Jakarta Sinar Grafika, 2012.

Undang-Undang Nomor 21 Tahun 2008 tentang Perbankan Syariah. Lembaran Negara Republik Indonesia Tahun 2008 Nomor 94.

Wawancara pribadi dengan Penambih Bambang Setijono, Bengkulu, 25 Februari 2016.

Wawancara pribadi dengan Tanti Widya, Bengkulu, 15 Februari 2016.

Wawancara Pribadi dengan Ainul Yaqin, Bengkulu, 20 Maret 2016. 